\title{
Mística e antimística, simbolismo e crítica literária
}

\author{
Mysticism and antimysticism, symbolism and literary criticism
}

\section{Eduardo Guerreiro Brito Losso}

Doutor em Letras

Professor da Universidade Federal do Rio de Janeiro

edugbl@msn.com

Resumo: Defendendo a hipótese de que a mística é a base fundamental de uma tradição delirante que atravessa a parte mais significativa da poesia moderna, o artigo discute como que as reações antimísticas à linguagem extravagante de escritores apofáticos e visionários se encontram tanto no controle eclesiástico, no racionalismo iluminista, quanto na crítica literária e humanista moderna. A ala antimística traça a abominável estratégia de transformar um acontecimento histórico literário e comportamental extremamente progressista, na maior parte de sua irrupção, em antiquado, reacionário, de modo a ser banido da cultura avançada para, de fato, passar somente a ser apreciado por tradicionalistas. Contra tal deturpação ideológica, o artigo propõe uma retomada do potencial transgressivo da mística a partir da releitura simbolista dela.

Palavras-chave: mística, simbolismo, crítica literária.

\begin{abstract}
Defending the hypothesis that mysticism is the fundamental basis of a delirious tradition that runs through the most significant part of modern poetry, the article discusses how the antimysticism reactions to the extravagant language of apophatic and visionary writers are found both in ecclesiastical control, in Enlightenment rationalism, as well as in modern literary and humanistic criticism. The antimysticism side traces the abhorrent strategy of transforming an extremely progressive literary and behavioral historical event, in the most part of its irruption, into an antiquated and reactionary one, in order to banish it from the advanced culture so that it become appreciated only by traditionalists. Against this ideological misrepresentation, the article proposes a resumption of the transgressive potential of mysticism from the symbolist re-reading of it.
\end{abstract}

Key words: mysticism, symbolism, literary criticism. 


\section{1- Tradição e mediação}

No último capítulo do livro Dialética negativa, intitulado "Meditações sobre a metafísica", Theodor Adorno descarta a questão epistemológica kantiana sobre como a metafísica é possível para substituí-la pela questão histórico-filosófica sobre "se a experiência metafísica ainda é efetivamente possível”. Indaga-se se uma experiência extática é viável, não na eternidade, mas dentro do caráter imperfeito e perecível da temporalidade.

O que significa, aqui, "experiência metafísica" se, para Kant, os dois termos não poderiam, de forma alguma, estar juntos? Afinal, não são contrários? Sem dúvida, e é nesse nervo de contradição entre imanência e transcendência que Adorno pretende se instalar, enquanto filósofo da história. E qual o fenômeno histórico que melhor incorpora essa contradição? Não se pode evitar de mencionar aquilo que o materialismo sempre viu com muita suspeita: "O nome do corpo da mística judaica, a cabala, significa tradição. A imediatidade metafísica, lá onde ela avança o máximo possível, não nega o quanto ela é mediatizada" (ADORNO, 2009: 311).

A experiência de uma imediatidade espiritual, se existe, e alcançando o mais longe que puder, trai, na etimologia da categoria clássica judaica - cabala - uma inevitável mediação. Ela não o nega: a mística lida com a tensão entre a autoridade tradicional e instantaneidade íntima do arrebatamento. Nos seus dois polos, ela expõe transitoriedade.

Mas de onde Adorno tirou essa informação? Gerschom Scholem (este famoso amigo de Walter Benjamin é o importante historiador da mística judaica), numa carta datada de 4/06/1939, em resposta ao interesse de Adorno pela sua tradução do livro Zohar, elucida que "cabala significa, nomeadamente, em alemão, tradição", e não "experiência originária" (Urerfahrung). Seus maiores visionários empregaram grande energia em comentários a respeito (SCHOLEM, 1994: 275. Tradução nossa). A primeira frase de A cabala e seu simbolismo, de 1960, insiste: “A Cabala, literalmente 'tradição', isto é, a tradição das coisas divinas, é a suma judaica" (SCHOLEM, 1978 [1960]: 7) . O que possui tradição tem história, acúmulo de transmissão geracional - não eternidade. O místico está imbuído de sua cultura sagrada e, por querer revitalizá-la radicalmente, representa "o perigo de um incontrolado e incontrolável desvio [Abirrung, aberração] em face da autoridade tradicional": seu modo de fortalecer a tradição é pô-la em cheque (SCHOLEM, 1978 [1960]: 26; SCHOLEM, 1973: 29). 


\section{2- Tradição delirante}

Será que o modo do místico se relacionar com a tradição não é "correto", é desviante? E nesse caso ele acabaria conduzindo não a uma tradição da autoridade, ao contrário, a uma tradição delirante? Consultemos a etimologia de 'tradição': vem do latim traditio, que por sua vez deriva de tradere, "transmitir posse, ceder", formado de trans (além, adiante) e dare (dar, entregar). A tradição transmite, passa, de uma geração a outra, um conhecimento especial e sagrado.

"Delírio" vem de deliriare (estar louco), que provém da junção de de (para fora) e lira (sulco do arado; lira aqui não é o instrumento musical, com o qual muitos produzem uma etimologia fantasiosa e não poucas belas rimas . Delirar é, portanto, sair fora do sulco do arado, isto é, desviar-se da linha. Tradição delirante é, então: a transmissão daqueles que se desviam da norma, da conduta correta. Estes necessariamente devem irritar os guardadores da boa conduta, da razoabilidade, da retidão.

Para que não se perca a direção certa, é imperioso conter-se, controlar-se. Tal inibição expressiva Cruz e Souza, poeta negro simbolista brasileiro, não admite, quando, no poema em prosa "Volúpia", de Outras evocações, deixa-se devanear em "infinitamente gozar todos os Grandes Amados, os curiosos sensi-bilizados do Pensamento e da Forma". Quem seriam essas personalidades tão queridas do poeta? Quem é capaz de o levar a se deleitar

nas suas vivas páginas evocativas, sagradamente, com emo-ção e paixão, incendiando-me nas suas chamas, perdendo-me nas suas lânguidas e extravagantes Arábias de Sonhos, subindo aos seus crepi-tantes delírios, às suas alucinações e crises nervosas que a mentalidade gera, mergulhando com intensidade, com profundidade, nas suas pode-rosas sensações (CRUZ E SOUSA, 1995: 714).

Possivelmente Cruz e Souza se refere aos próprios escritores que admira. Vale assinalar como ele reconhece neles a capacidade de abrasar dionisiacamente a sensibilidade do leitor, não, contudo, com mera liberação psicótica, mas com o trabalho do "Pensamento e da Forma", destacados com maiúsculas. Quem o leva a "crepi-tantes delírios" faz parte, portanto, de seu panteão, de sua tradição delirante: são aqueles que sabem delirar verbalmente e fazer delirar, não com meras exaltações, mas com 
extravagâncias formalmente elaboradas, para que sejam capazes de conduzir o leitor a elevar-se e imergir-se, sair do mundano e adentrar em outros espaços oníricos, "Arábias", encantadoras "alucinações". São pessoas de sensibilidade especial que se dirigem a leitores da mesma índole de modo a formar, assim, uma sorte de comunidade de intimistas solitários.

Claro que toda essa farta pompa imaginativa - "os esparramamentos e os jactos logorreicos" (MOISÉS, 1966: 222) - é facilmente ridicularizável. Boa parte dos críticos não perderam tal oportunidade. A começar por Araripe Júnior, que, no calor da hora, em 1894, no artigo “Movimento literário de 1893” zomba da estetização da liturgia própria do simbolismo, bem ostensiva em Cruz e Sousa: “Assim nasce o Missal. O autor, no silêncio, deixa-se assoberbar pelo delírio das grandezas. Julga-se já um sacerdote; reveste-se dos paramentos pintalgados que dançam em seu cérebro e promete pontificar" (CAROLLO, 1981: 201). A ironia é especialmente maldosa sabendo-se ser neste artigo que Araripe, demarcando o fato de ser o primeiro negro "sem mescla" que se torna "notório pelo talento" em nossas Letras, denomina-o de "ingênuo no meio da civilização ocidental" (CAROLLO, 1981: 199-200). Não satisfeito em escarnecer do poeta pela musicalidade supostamente verborreica, associa-a à uma pretensão sacerdotal que se torna signo claro de ingenuidade própria de sua raça diante da vida civilizada carioca. Em outras palavras, nada mais chinfrim do que um negro interiorano bravateando "delírios de grandezas"; e pior: grandezas espirituais.

Araripe Júnior não esconde que sua mofa pelo nosso "Dante negro" está ligada a uma repulsa mais geral pelo simbolismo: "Fossem porém o que fossem extravagantes, repetidores de coisas já conhecidas, malucos ou neurastênicos, o que é certo é que esse acidente literário, chamando a atenção de Paris, tornando-se objeto de interwiuss, transformou-se em moda e alastrou o mundo" (CAROLLO, 1981: 190). Extravagantes porém inautênticos, malucos porém contagiosos, José Veríssimo concorda com seu colega que os simbolistas brasileiros são "tão vazios de fundo quão extravagantes de forma" (CAROLLO, 1981: 368), forma caracterizada essencialmente pela "falta de concisão e de precisão", própria de "nefelibatas, estetas, místicos, decadistas" (CAROLLO, 1981: 365). Os dois grandes críticos oficiais da literatura brasileira neste período combinam um pacto implícito: é preciso conter a excentricidade dos novos. 


\section{3- Antimística}

Místicos? Retrocedamos alguns séculos. Ninguém menos que o clássico poeta e crítico literário Nicolas Boileau (1636-1711) disse que "Os místicos são modernos; não se via deles na Antiguidade" . Como adversário dos Modernes e representante dos Anciens, sabemos que se referindo a eles dessa forma, o autor da frase está querendo dizer que seu estilo é de muito mau gosto. Boileau não o vê senão como novidade passageira (BEAUDE, 1990: 7). Ele está do lado de um dos maiores antimísticos da história: Jacques-Bénigne Bossuet (1627-1704).

Bossuet exorta a seus fiéis leitores que não abram nenhum espaço "àqueles novos místicos"; cita o nome dos livros que não devem ser lidos, que contém "teologia pouco correta, expressões e exageros irregulares de certos místicos irrefletidos ou mesmo presunçosos", “com suas novidades profanas de linguagem”. No livro Instruction sur les états d'oraison (1697), ele os acusa de "introduzir uma nova linguagem na Igreja que os leva a contradições" (BOSSUET, 1841: 26). "Não se deve esperar nem justeza nem precisão nestas expressões estranhas". "O que parece ter inspirado essa linguagem exagerada é que, tomando como modelo os livros atribuídos a são Dionísio Areopagita, eles o imitaram no estilo extraordinário" (BOSSUET, 1841: 27; CERTEAU, 2015: 171). Aqui o alvo de ridicularização é Jan van Ruysbroeck (1290-1381), o místico flamengo: precisamente aquele com o qual Maurice Maeterlinck, o simbolista belga, vai-se encantar e traduzir em 1891.

O ataque antimístico do século XVII à flagrante modernidade dos místicos é, sem sombra nenhuma de dúvida, muito diferente da desaprovação dos críticos literários ao simbolismo. Ele tinha, por trás de si, várias condenações à morte de místicos na inquisição. Vale mencionar, especialmente, que uma das mais importantes beguinas, Marguerite Porete (1250-1310), foi queimada publicamente em Paris no dia 1 de junho de 1310, sob acusação de heresia, por ter escrito o livro Le Miroir des âmes simples (O espelho das almas simples), que, por sua vez, muitos defendem ter influenciado um dos maiores filósofos alemães, o místico Meister Eckhart (1260-1328), do qual Martin Heidegger pegou de empréstimo conceitos como Gelassenheit (serenidade) e Abgeschiedenheit (desprendimento).

Desde o nascimento da mística cristã stricto sensu, no século XII, já havia uma tradição (antidelirante) de condenação de suas práticas meditativas, reflexivas, 
intelectuais e literárias. Quando, no século XVI-XVII, ela é a acusada de ser "moderna", a palavra continha um sentido de incriminação, a ponto de, mesmo no final do sec. XVII, ainda ser capaz de aprisionar as imperdoáveis ousadias quietistas de Madame Guyon (1648-1717; ela foi aprisionada na Bastilha de 1695 a 1703) e mesmo seu defensor, o teólogo Fénelon (1651-1715; foi banido da corte em 1700), caso esse que se tornou bastante famoso e até hoje é um capítulo frequentemente revisitado da história da França. Quem foi o grande responsável por acusar e incriminar ambos? Bossuet.

Já quando os críticos literários do fin de siècle desqualificam o simbolismo tanto por causa de suas pretensões de instaurar uma "Religião da arte" quanto pelo estilo extravagante (mesmo que este se torne o ponto de partida das celebradas inovações modernistas), os simbolistas não são nem queimados nem encarcerados por isso. No caso do Brasil, eles só são menosprezados, apagados e quase esquecidos. Não é pouco.

É na mais estrita diferença histórica que começam as semelhanças. Os místicos foram um dos tipos sociais que mais sofreram na pele as agruras de empregar uma linguagem original, esquisita e consequentemente ser moderno. Não se pode deixar de suspeitar que provavelmente foi o místico quem sofreu a mais grave opressão por tais motivos, e não os modernistas - nossos heróis. Ao mesmo tempo, desde o modernismo que os místicos tendem a ser considerados (geralmente por quem os desconhece e não os estuda), tanto por um senso comum acadêmico quanto até por um senso comum laico cultural como: conservadores (HANEGRAAFF, 2012: 77-152).

Semelhantemente, os simbolistas, especialmente no Brasil, defenderam a bandeira dos novos, insurgindo-se contra o meio acadêmico da literatura e da arte, engajando-se como republicanos e abolicionistas, publicando revistas e livros introduzindo versos livres, poemas em prosa, inovando o vocabulário, enfrentando a linguagem comum com uma escrita difícil e singular, confrontando a ideologia burguesa com uma vida boêmia avançada e tendo, inclusive, como seu representante principal um negro "sem mescla". Influenciou o hoje chamado "pré-modernismo" brasileiro, que é visto como diferente do simbolismo por razões mais do que duvidosas (em outros países tal diferença não está clara) e, evidentemente, nossos grandes modernistas nasceram de seu ninho e não do parnasianismo dominante. Porém, passou-se o tempo, e o que é dito em seguida? O simbolismo foi um movimento conservador, cópia dos franceses, inautêntico e sem brasilidade.

Não é possível aqui examinar em detalhe os meandros dessa história. Pretendemos, no momento, chamar atenção para o questionamento da narrativa 
dominante, hoje canônica, de menosprezo do simbolismo brasileiro, a partir do descarte mais fundamental da literatura mística, que parece estar na base de um fenômeno ainda ignorado da história da cultura: como um acontecimento histórico literário e comportamental extremamente progressista, na maior parte de sua irrupção, é reescrito como antiquado, reacionário, de modo a ser banido da cultura avançada para, de fato, passar somente a ser apreciado por tradicionalistas?

E por que, justamente, tais acontecimentos fazem parte de uma reincidência cultural específica - cuja linhagem podemos chamar de tradição delirante?

\section{4- Mística, história e delírio}

O delírio dos místicos é feito do que eles acreditam ser uma "visão espiritual e sobrenatural” (RUYSBROECK, 2001: 44), para usar as palavras de Ruysbroeck traduzidas por Maeterlinck. Já o delírio dos simbolistas produz uma estetização dos símbolos religiosos com vistas a uma espécie de religião da arte, que, se for para ser franco, não é religião - reconduz a energia extática e entusiástica dela para o campo artístico. Ambos sofrem de sede de infinito: “Tenho sede, tanta sede!” (RIMBAUD, 2007: 147), "E esta sede estranha/ Me escurece a entranha", diz o Rimbaud de Uma estadia no inferno; o homem que busca a Deus "se parece àquele que tem uma sede ardente", diz Ruysbroeck (2001: 25). Em suma: “o poeta é da raça dos incontentáveis”, sentencia Jorge de Lima (LIMA, 1997: 37).

E o infinito de Rimbaud se esbalda, precisamente, em imagens: "as alucinações são incontáveis [...] poetas e visionários morreriam de inveja. Sou de longe o mais rico, sejamos avaros como o mar [...] Sou mestre em fantasmagorias" (RIMBAUD, 2007: 149). Tamanha ousadia e petulância diante do passado de nosso enfant terrible, não nega, surpreendentemente, a tradição, pelo contrário: “As velharias poéticas entravam em boa parte na minha alquimia do verbo" (RIMBAUD, 2007: 165). Ele violenta, sim, a autoridade, isto é, a sua face opressiva; mas retém, especialmente em sua alquimia verbal, a transmissão de passados esquecidos, ocultos.

Segundo Scholem, nunca a visão de um místico vai apresentar traços diferentes de seu entorno social e histórico: por isso um contemplativo do séc. XIII não verá automóveis nem celulares. Da mesma forma, quando o historiador da cabala e teórico da mística se pergunta "o que acontece quando um misticismo não apresenta nenhum laço 
com autoridade religiosa alguma", responde que, mesmo havendo autores que rejeitam "toda autoridade tradicional", os mesmos vestem "a interpretação com a mesma experiência de imagens tradicionais. Eis o que ocorre com Rimbaud [...] Eles se consideram hereges luciferianos, porém sua imaginação é permeada de imagens tradicionais" (SCHOLEM, 1978: 25). Em outras palavras: os mais ostensivos transgressores da modernidade dependem de sua tradição cultural tanto quanto o mais do que suspeito tradicionalismo dos místicos medievais e renascentistas. Ironicamente, o delírio, místico ou simbolista, carece de tradição.

É essa contraditória dependência e irreverência frente à tradição que une a mística ao simbolismo. Ela justifica a ideia de uma tradição transviada, que sai dos trilhos de como se deve controlar e restringir o potencial vital da própria tradição. O que justifica nosso propósito, a partir daí: é preciso defender o uso livre, desobediente e autotransformador da tradição na literatura, no pensamento, na intimidade e no comportamento. Uma das fontes tradicionais mais ousadas para se retomar é precisamente a dos místicos, e a mais intensa releitura poética dos místicos feita no séc. XIX foi a do simbolismo, seguido, no século XX, pelo surrealismo. Essa é a tríade histórica da tradição delirante.

Afinal, de onde vem o conceito de tradição delirante? Retornemos ao Brasil do séc. XXI. Ericson Pires, um dos poetas do movimento de poesia Azougue, no livro Cidade ocupada, resultado de uma tese de doutorado, procura explicar sua inauguração: "O delírio faz a tradição se deslocar, trair a si mesma" (PIRES, 2007: 12) , o que, como vimos, ajusta-se bem à etimologia das palavras. A tradição se desvia a partir de sua própria tradução: “A tradução é o movimento da tradição inventada pela traição" (PIRES, 2007: 164). O que interessa à tradição delirante é o incessante desvio da tradição dominante por meio do modo como a primeira traduz a segunda.

Ericson retira o sentido positivo de "delírio" de Deleuze. O filósofo francês afirma que o escritor "inventa na língua uma nova língua, uma língua de algum modo estrangeira [...] Arrasta a língua para fora de seus sulcos costumeiros, leva-a a delirar”. É muito significativo que Deleuze se refira a "visões e audições não-linguageiras, mas que só a linguagem torna possíveis. Por isso há uma pintura e uma música própria da escrita, como efeitos de cores e de sonoridades que se elevam acima das palavras”, para, daí, diferenciar as visões do escritor daquela do psicótico, que levariam ao sofrimento e caracterizariam um estado doentio. As visões da escrita, ao contrário, não são doentes: “A literatura é uma saúde" (DELEUZE, 1999: 9). 
A sinestesia simbolista seria, então, sinal de boa disposição. Se ela não deixa de derivar de experiências com alucinógenos, ela quer ser uma espécie de alucinação esclarecida, isto é, elaborada verbalmente; para usar uma formulação de Benjamin referente ao surrealismo: uma iluminação profana (BENJAMIN, 1994: 23-24).

Deleuze se baseia em Proust, que, segundo vários críticos, entre eles Edmund Wilson (WILSON, 1967: 100-136), está diretamente ligado ao simbolismo. E sua noção de que há pintura e música na literatura corrobora tal hereditariedade. Ericson Pires cita o último trecho de Deleuze e adere com paixão a todo o seu jargão, repetindo muitos motes teóricos dos quais estamos hoje um tanto enfastiados, contudo, o que ele seguramente acrescenta está na sua intuição certeira de que "há tradições de experimentação e ruptura ao longo da história cultural brasileira" (PIRES, 2007: 183), remetendo diretamente a diversas manifestações da história da arte no Brasil: Flávio de Carvalho nos anos 20 e sua Experiência n. 2, neoconcretismo, Hélio Oiticica, Lygia Clark, Ligia Pape dos anos 60 e 70, Waly Salomão, entre outros. Todos possuem em comum um "aspecto delirante" que se desvia da "tradição standard nacional" (PIRES, 2007: 183) e da critica. Já Renato Rezende, outro poeta da Azougue, serviu-se em sua tese de doutorado (na qual fomos membros da banca) do insight de Ericson Pires para, na mesma área das artes, desdobrar mais leituras de Flávio de Carvalho, neoconcretismo e arte contemporânea nessa chave (REZENDE, 2007: 94).

Embora Ericson tenha criado o conceito e dado a ele o delineamento básico, apontando seu potencial de tocar no problema chave das principais tendências da crítica brasileira de desvalorizar experiências artísticas excessivas e extravagantes, o autor se confunde com a generalização deleuziana de que toda a literatura e arte é essencialmente delirante. A pergunta que devemos colocar é a seguinte: estamos falando de um tipo de arte ou da arte e literatura como um todo? A nosso ver, a generalização dilui o enorme potencial crítico do insight de Ericson. Para que ele se explicite, é preciso imergir a fundo no que seria, de forma mais determinada e determinante, as raízes da tradição delirante, não só em Flávio de Carvalho e no neoconcretismo, mas naquele movimento literário que, seguramente, é o precursor, promotor, defensor e praticante fundamental do delírio literário moderno: o simbolismo.

Se Ericson não toca nem na mística, nem no simbolismo nem no surrealismo (somente em Artaud), ele perde, inclusive, a especificidade da ideia de delírio verbal ao qual Deleuze se baseia, e cuja fonte é simbolista. Nosso intuito, então, é especificar a tradição delirante em relação a outras correntes literárias e artísticas para aproveitar o 
potencial genuíno do conceito, com vistas a tirar do abandono o movimento simbolista brasileiro, desde o início jogado na penumbra e, a partir de seu gosto pelos excessos estilísticos, acompanhar o desenrolar da tradição delirante posterior, cujo ponto de chegada se encontra em toda a produção crítica e editorial de Sergio Cohn e sua editora Azougue, que tem feito um esforço inédito tanto de retomada dessa memória quanto de sua revitalização e atualização produtiva no movimento da revista Azougue, desde os $\operatorname{anos} 90$.

Dar uma perspectiva crítica renovada à valorização do simbolismo brasileiro e suas derivações subsequentes, em específico e, no pano de fundo tradicional dela, entrever o papel fundamental da literatura mística medieval e renascentista para a eclosão do delírio moderno é, também, um modo de mostrar a conexão íntima, inventiva, entre momentos históricos distintos, em que um ilustra reciprocamente o outro. O propósito desafiador desse projeto de releitura da poesia brasileira inclui, necessariamente, o compromisso ético de retirar da sombra e do desprezo trabalhos libertários de grande valor, ao buscar exercitar nossa acuidade crítica para compreendê-los e traduzi-los a olhos que a princípio não veem neles senão verborragia, vã pretensão, “delírios de grandezas".

Não só se torna perceptível, nas semelhanças e diferenças dos simbolistas aos místicos, de que forma os primeiros fazem da figura do monge uma curiosa metáfora do recolhimento do poeta incompreendido na cidade burguesa, como também observar os místicos com olhos simbolistas torna mais visível o seu caráter subversivo, arredio, indócil frente ao controle implacável da Igreja. Os místicos são, em sua maioria, libertários: basta retirar sua leitura de um espaço teológico conservador e pedir ajuda de seus filhos legítimos em fervor e extravagância. Quem nos ajuda especialmente aqui, no âmbito internacional, é Maeterlinck; no nacional, Dario Veloso. Ou seja: a enorme diferença entre místicos e simbolistas (que estamos longe de ignorar, na sua abismal distância histórica) é aquilo mesmo que garante a riqueza de sua cintilante afinidade eletiva - o pendor delirante - para nos servirmos de um conceito que se origina da alquimia e ao qual Michael Löwy (LÖWY, 1989: 13-18, 169-170) defende, com insistência e propriedade, um uso rigorosamente metodológico. 


\section{5- Simbolismo e história da mística}

\subsection{Simbolismo e romantismo}

Primeiro aspecto metodológico a ser considerado é como tratar dos períodos literários. É muito comum na teoria literária, já faz algum tempo, duvidar de sua importância, seja porque eles dão a impressão de uma história linear em que vão se sucedendo sem dar conta de uma simultaneidade múltipla e distinta de fatores históricos, seja porque eles não compreendem os casos de obras e autores mais singulares, que sempre ultrapassam as características de um movimento, seja porque as fronteiras entre uma geração e outra são mais do que imprecisas, seja porque a própria simultaneidade indiferente de estilos do contemporâneo determinou nossa releitura do passado. As falhas patentes da periodização a partir dos movimentos provocou um anseio de superação deles. Contudo, dificilmente será possível falar de um momento histórico sem denominá-los e, mesmo que seja para desconstruí-los, é preciso estudá-los. Logo, não há, a rigor, ultrapassagem possível na relação com os diferentes períodos: há, a partir de certa ruptura com um olhar crente e ingênuo diante deles, um uso carregado de desconfiança, desmistificado. Bem ou mal, eles criaram um quadro básico de fenômenos estéticos. Só podemos precisar a singularidade de um acontecimento literário, em relação a eles, a partir deles. Nesse caso, nossa proposta é tomar um dos períodos como eixo histórico de uma tendência delirante da literatura que atravessa os tempos. Outros teóricos fizeram o mesmo, isto é, utilizando um período com base para leitura de um caráter geral.

Não à toa, um dos melhores pensadores da poesia moderna, decisivo para nossos propósitos, sustenta que o romantismo é não só o primeiro movimento literário da modernidade, mas também o mais importante: Octavio Paz. Paz justifica a raiz protestante, inglesa e alemã, do romantismo e sua ruptura radical de visão de mundo e mesmo de "crença" em relação ao passado. Sua recusa do formalismo neoclássico quis inundar a vida de uma visão analógica do universo animada pelo ritmo verbal, que se revitaliza a partir da poesia popular, em sua simplicidade e sensibilidade, contrárias ao artificialismo do engenho (PAZ, 1984: 83-92).

Quando Paz desembarca no "modernismo" de fim de século hispano-americano, que, diga-se de passagem, é o simbolismo (a figura central é Ruben Dario), julga que "O modernismo foi o nosso verdadeiro romantismo e, como no caso do simbolismo francês, 
sua versão foi uma metáfora e não uma repetição: outro romantismo" (PAZ, 1984: 117). Agravando a confusão dos termos, Paz reduz o simbolismo a um segundo momento do romantismo e, no caso da América hispânica, acredita que esse foi o seu verdadeiro romantismo. Entretanto, é ele mesmo que rejeita o romantismo "dos manuais", de Musset e Lamartine, e assinala o verdadeiro: Nerval, Hugo do período final, herdeiros diretos do romantismo inglês e alemão de Blake e Novalis: "Na realidade, os verdadeiros herdeiros do romantismo alemão e inglês são os poetas posteriores aos românticos oficiais, de Baudelaire aos simbolistas" (PAZ, 1984: 91). Ora, que ideia mais confusa: o verdadeiro romantismo é justamente aquele que vai dar no... simbolismo? O melhor romantismo é aquele que será o precursor precisamente daquilo que entendemos por simbolismo e, no entanto, o simbolismo é o verdadeiro romantismo?

A nosso ver, Paz se complica: argumenta a favor da centralidade do romantismo na modernidade, embora rejeite em bloco o romantismo oficial e selecione somente aquele da analogia, da subversão rítmica e transgressão antiburguesa para, afinal, indicar o desabrochar do romantismo autêntico no... simbolismo. De fato, a tradição da ruptura de Paz é, em grande parte, aquilo que entendemos por tradição delirante. Mas faltou alguém dizer ao brilhante teórico mexicano que o eixo central, o manjar, não está propriamente no romantismo, está no olhar visionário do simbolismo. Afinal, é o simbolismo e, posteriormente, o surrealismo que vão filtrar aquilo que interessa do romantismo.

Portanto: em nosso ponto de vista da história da poesia, pretendemos trabalhar com a ideia de que é o simbolismo, e não o romantismo, o eixo central do que mais interessa da poesia moderna. É nele que se situa o despontar nítido e real da tradição delirante, sendo o surrealismo, em seguida, o seu principal desdobramento.

\subsection{Mística}

Segundo aspecto metodológico a ser considerado é como tratar, numa pesquisa acadêmica, a mística como objeto de estudo. Antes de mais nada, imprescindível formular as seguintes questões: é preciso acreditar na mística e defendê-la fervorosamente como a verdade ad vitam aeternam e fonte dos segredos da anima mundi para estudá-la? Ou, no outro polo extremo: é preciso exibir sem parar todas as formas possíveis de repulsa e distanciamento da mística para ser levado a sério quando se toca nela em estudos 
acadêmicos? Será que a mística é algo tão atraente e perigoso assim? Ela deve mesmo sempre exigir de todo estudioso universitário uma postura tão tensa e desconfortável? Ame-a ou deixe-a?

Se não entendermos o que está por trás dessa polarização congelada que teve seu período de explosão em outros tempos e até hoje não nos permite experimentar um ambiente mais distenso e desapaixonado, não será possível nenhum avanço. É imperativo - caso desejemos nos ocupar do assunto, como é o nosso caso - um esforço de larga reflexão epistemológica e metodológica a respeito do lugar da mística na sociedade ocidental, o modo de abordagem dela nas ciências humanas e a especificidade de sua relação com meios e sistemas literários (GRUBER, 1997: 19-21).

Em primeiro lugar: a dispensa da mística nos espaços públicos está ligada a um antagonismo institucional e ideológico entre cultura laica e cultura religiosa no Ocidente. A Europa foi a primeira grande civilização que iniciou uma radical rachadura entre Estado e religião. O nascimento das ciências está diretamente ligado a uma rejeição insistente e laboriosa não só de crenças religiosas, míticas, supersticiosas, como também de todo um vocabulário, gestualidade, ritualística, ocupações e ambientes de convívio. Enfim: a conquista do espaço laico, artístico, científico ou acadêmico, dependeu, num primeiro momento, de violentas rachaduras culturais e, num segundo, da construção de muros. Lá na Igreja faz-se assim, aqui não. Não precisamos lembrar ao leitor o esforço constante do professor de garantir a frágil independência dos espaços laicos educacionais (MÜLLER, 2003: 74).

"Mística" é uma palavra que significa muitas coisas. Procurar diferenciar "misticismo" de "mística", tentar enobrecer uma para dispensar outra como estratégia de se enobrecer academicamente, não necessariamente ajuda. Vamos trabalhar agora com dois fenômenos históricos concretos, mas bem diferentes, aos quais ela está ligada. $\mathrm{O}$ primeiro é aquilo que eu chamo de mística stricto sensu: uma literatura do séc. XII ao XVII derivada do monasticismo mas bem diferente dele, composta majoritariamente de tratados de elevação da alma que privilegiam ou o arrebatamento visionário ou o momento extático da participação da alma esposa em Deus, isto é, no Cristo esposo, cuja ápice anagógico desenvolve uma sofisticada teologia negativa (vinda de fontes da patrística, neoplatonismo e de pseudo-Dionísio Areopagita, inventor da teologia negativa cristã), diferentemente da preocupação dominante do monasticismo no momento purgador, ascético, de controle dos corpos e pensamentos. Foi esse fenômeno que fez surgir escritoras beguinas, místicos germânicos especulativos e místicos do século de 
ouro espanhol. Algumas dessas personagens históricas foram inteiramente ou parcialmente aceitas pela Igreja depois de seu conflito com ela em vida, outras nunca o foram. De qualquer modo, a teologia geralmente se ocupa delas e lhes atribui distinção, enobrecendo-a, diante de qualquer coisa que cheire a "esoterismo". Aqui percebemos que a área mais tradicional e não laica da academia edificou, depois de um bom tempo de conflito, um certo abrigo a essa mística, como um tesouro de seu saber acumulado.

Os nomes mais representativos são: Hildegard de Bingen (1098-1179), a mais importante visionária medieval, no sentido estrito do termo; seu amigo Bernardo de Claraval (1090-1153), enquanto introdutor da mística nupcial; Marguerite Porete (12481310), a mais ousada beguina; Meister Eckhart (1260-1327), considerado o primeiro grande filósofo dialético alemão, traduzido pelo anarquista Gustav Landauer em 1903 (ECKHART, 1903); Jan van Ruysbroeck (1293-1381), traduzido por Maeterlinck em 1891; Teresa de Ávila (1515-1582), a mais citada pelos simbolistas brasileiros ; João da Cruz (1542 - 1591), que mereceu um ensaio de Valéry (1957: 445-457).

O segundo é aquilo que chamamos de filósofos da natureza renascentistas, ou filosofia oculta, hermetismo, cuja doutrina da semelhança foi estudada por Foucault em As palavras e as coisas (FOUCAULT, 2000, capítulo “A prosa do mundo": 23-62), mas cuja primeira grande desbravadora do assunto é Frances Yates, em Giordano Bruno e a tradição hermética, existente do século XIV ao XVII. Estes também mantém o horizonte dos tratados de elevação, incluem a teologia negativa a partir do neoplatonismo e Dionísio, porém eles produzem, além disso, um sistema cosmológico e alquímico que propõe uma magia culta, erudita, elevada, integrando-se a fontes pagãs (textos atribuídos a Hermes Trismegisto) e cabala, cristianizando-os (YATES, 1995: 30). Assim, ao mesmo tempo que absorvem algo do saber mágico popular, pretendem elevá-lo à chave gnóstica de leitura da assinatura oculta das coisas, encontradas através de analogias sutis entre diferentes elementos terrestres e corporais, entre a terra e o céu, entre o mundo celeste e o supraceleste. Embora eles tivessem a ambição de iniciar uma reforma da Igreja, a teologia viu neles uma inaceitável ameaça para sua pura espiritualidade. Yates argumenta que foi esse olhar ávido de retirar conhecimento não só de conceitos abstratos e experiências tidas como espirituais, mas da própria natureza, que preparou a vinda da ciência no século XVII .

Citemos Agrippa von Nettesheim (1486-1535), o grande sistematizador da "filosofia oculta" e autor de um surpreendente livro feminista (AGRIPPA, 2007); Giordano Bruno (1548-1600) frade dominicano acusado de panteísmo, por defender a 
infinitude do universo, condenado à morte na fogueira ; Tommaso Campanella (15681639), também dominicano, autor da obra utópica Cidade do sol (1623); Jakob Boehme (1575-1624), grande visionário teósofo que influenciou todo o esoterismo francês e idealismo alemão.

O que essas duas místicas possuem em comum, além das emanações neoplatônicas, teologia negativa e busca ávida de realidades divinas indizíveis é mesmo um sedutor "delírio de grandezas", sem, contudo, conquistar nada de concreto para além dos sublimes encantamentos subjetivos que tais visões de mundo produzem em quem as produz e estuda, o que tanto irrita a sensatez de modestos cientistas, burgueses cobiçosos de resultados lucrativos e eclesiásticos sisudos de sua sagrada autoridade.

Contudo, a máthêsis universal do século XVII precisou de uma violenta abominação desse saber hermético para que pudesse desenvolver o seu real domínio empírico da natureza. Foi nessa época que apareceram as primeiras histórias da filosofia alemães, que, primeiro, contestaram veementemente os filósofos naturais para, em seguida, reduzirem-nos a pequenas notas desprezíveis e, num terceiro momento, apagarem tais nomes e assuntos de suas histórias. Tais historiadores protestantes iluministas pretendiam separar o "joio" do "trigo", praticando um combate antiapologético que via no neoplatonismo hermético uma contaminação pagã sincrética no cristianismo: Jacob Thomasius (1622-84), Christian Thomasius (1655-1728), Christoph August Heumann (1681-1764) e o mais brilhante, Johann Jacob Brucker (1696-1770). Eles foram antimísticos ainda mais bem-sucedidos que Bossuet (HANEGRAAFF, 2013: 56-69). Foram eles que estabeleceram ao mesmo tempo o espaço laico e o descarte da filosofia oculta da academia. Assim, enquanto a verdadeira ciência nascente ganha espaço na universidade, a filosofia hermética é rejeitada impetuosamente tanto pela Igreja quanto pela ciência, até virar um saber inútil, infrutífero, vão, cultuado em meios esotéricos (é no século XVII que nascem sociedades Rosacruzes) mas enxotado de qualquer espaço público e indigno de atenção.

Entretanto, ela não desapareceu assim tão fácil. Foi justamente um cientista, fundador da academia sueca, que resolveu se converter a ela e se arvorar a sábio conhecedor do mundo espiritual: Emanuel Swedenborg (1668-1773), o criador da teoria das correspondências, sucesso best seller de seu tempo, escreveu uma obra imensa de dezenas de tomos propondo uma nova versão da analogia oculta. Ela fará a passagem dos restos de hermetismo renascentista para o século XVIII. O poder de encantamento da semelhança encontrou aí novo vigor. Swedenborg foi alvo de ataque do maior dos 
filósofos iluministas, Immanuel Kant, que lhe dedicou um livro (KANT, 1976; KANT, 1989; DAVID-MENARD, 1996). Serviu como exemplo central, inclusive, para que Kant entendesse melhor a estrutura ilusória da metafísica como um todo.

Muitos se aborreceram profundamente com Swedenborg, mas boa parte dos românticos se maravilharam com ele até tal admiração atingir escritores da estatura de Balzac e Baudelaire. Nesse meio tempo, Louis Claude de Saint-Martin (1743-1803) redescobre fascinado Jakob Böhme (assim como, no campo literário e filosófico, Novalis, Schelling, Hegel que, por sinal, também leem com fervor os místicos estritos, como Eckhart) e o traduz para o francês, fundando assim o martinismo. A partir daí, floresce um profuso esoterismo e espiritualismo francês, por vezes misturado com o socialismo (exemplo claro disso é Charles Fourier, 1772-1837), em ondas de moda que atingem a primeira metade do século XIX e chegam na segunda influenciando decisivamente vários precursores do simbolismo para terminar por se fundir com o próprio. Tal cooperação foi estudada com minúcia por Alain Mercier, em Les Sources ésotériques et occultes de la poésie symboliste (1870-1914) (MERCIER, 1969; MERCIER, 1974).

Tivemos de esboçar sinopticamente a base histórica das duas noções para apresentar com mais clareza o quanto a mística está intrinsecamente ligada à história da cultura ocidental. Ao mesmo tempo que ela foi dispensada do racionalismo iluminista, que passa a ser identificado com o "Ocidente", sua vertente oculta contribuiu para o surgimento da ciência, seja como precursora, seja como seu mais profundo antagonista. As vertentes mais significativas da literatura moderna acolheram esse saber de algum modo em seus anseios extáticos e utópicos (aliás, é na filosofia oculta que nasce a literatura utópica moderna ), até finalmente aparecer a assunção do idealismo simbolista.

Voltemos às questões do início: é preciso acreditar na mística para estudá-la? O gosto dos escritores modernos por ela serve para darmos mais crédito a seus delírios gnósticos?

Resposta: não. É possível mantermos uma abordagem estritamente materialista e histórica da relação das diferentes místicas com a literatura moderna, sem cairmos no canto da sereia de acreditar que seu deus esposo existe, ou que suas cosmologias alquímicas e astrológicas estão descrevendo os elos ocultos com uma realidade superior.

É preciso exibir sem parar todas as formas possíveis de asco e distanciamento da mística para ser levado a sério quando se toca nela em estudos acadêmicos?

Resposta: também não. Não vemos nenhum sentido em ostentar nosso materialismo com gestos constantes de aversão. Também não precisamos esconder que 
podemos perfeitamente nos deliciar com a leitura encantadora dos místicos, assim como os simbolistas, surrealistas, Fernando Pessoa, Guimarães Rosa e Borges o fizeram, sem necessariamente acreditar em suas doutrinas.

Há uma grande diferença entre a mística e a literatura moderna que se serve dela. A primeira produziu sim literatura de altíssimo nível, é uma das vertentes da fina flor da literatura medieval e renascentista, bem como da filosofia e teologia, também. Mas ela não é ficção. Acredita no que diz. A literatura moderna, diferentemente, buscou a autonomia da ficcionalidade, portanto não inclui convencimento nem de verdade nem de sistemas . É basicamente por isso que aceitamos os encantamentos e desencantamentos simbolistas, que é extremo nos dois pólos: seu decadentismo spleen é niilista; sua correspondência é um grande reencantamento do mundo. Como diz Octavio Paz, a poesia moderna é feita de analogia e ironia (PAZ, 1984: 102-103).

Contudo, agora aparece outra importante questão: por que não podemos apreciar a literatura e filosofia mística como ficção? Por que não é possível lê-la desencantado de suas verdades, mas deslumbrando-se com seus minuciosos exercícios poéticos de semelhança, bem como suas complexas especulações negativas, com a mesma liberdade da perspectiva textual de Borges ? Por que não é possível dar valor estético, antropológico e filosófico a essa parte essencial da cultura ocidental, e que o "Ocidente" fez de tudo para dispensar como o Outro de si mesmo? E nós, latino-americanos tupiniquins, seguimos essas mesmas polarizações da formação do poder e saber institucional de nossas ex-colônias, sem nenhuma visão minimamente crítica delas? Seguiremos implementando Ordem e Progresso nas universidades?

Não é preciso manchar a reputação racionalista do Ocidente levando em conta a riqueza mesma de seu irracionalismo pretensamente sistemático? Sim, pouco ou mal sistematizado no seu sincretismo, não importa, importa que a exigência de que a obra seja ausente de pretensões, seja somente ficcional, literária, não deveria ser nenhuma proibição para apreciações estéticas, ou para-estéticas, na fronteira confusa entre os saberes e os intuitos.

E mais: em tempos de radical questionamento dos resultados devastadores do racionalismo, base da tecnocracia que destrói o ecossistema planetário, enfim, em tempos de antropoceno, cientistas críticos e antropólogos filósofos estão apontando para o respeito à natureza praticado pela sabedoria indígena. Mania constante do Ocidente, hoje herdada pela globalização pós-moderna: para se contrapor ao seu racionalismo, ele foge de si mesmo e vai buscar sabedoria na Índia (o que ocorre desde os tempos do 
simbolismo), na China, no Japão e, é claro, como não poderia deixar de ser, nos índios latino-americanos; na Yoga, no budismo, no xamanismo - na Europa, não. Continuemos repudiando sua irracionalidade e cultuando a irracionalidade dos outros. Até que ponto isso não reflete justamente a ideologia imaculada do bom e velho Ocidente orientalista? Não é do seu interesse que continuemos seguindo esse modelo?

Não está na hora de colocar lado a lado delírios de homem branco com delírios de índios e negros, compará-los, diferenciá-los e, naturalmente, atentar para o seu potencial comum de crítica de uma visão de mundo dominadora da natureza? Curioso nisso tudo é que haja, sim, tal potencial na filosofia oculta, mesmo quando ela participa do desejo de dominar a natureza magicamente e antecipa a dominação tecnocrática em seus "delírios de grandeza" (YATES, 1995: 491-492). O que ela não tinha como realizar, sonhou. O que sua filha bastarda, a ciência, renegou, foi, justamente, o sonho, realizando-o empiricamente, monstruosamente. A filosofia oculta se tornou uma mãe renegada e quase que totalmente esquecida. Quase: não para as correspondências simbolistas, menos ainda para seus herdeiros do século XX e XXI. Há muito o que ser desvelado numa reflexão dialética de seu papel na história do esclarecimento .

Não são poucos grandes críticos que advogaram a favor do valor da mística e do esoterismo para a literatura e cultura moderna (André Breton, Octavio Paz, Harold Bloom, Walter Benjamin, Michael Löwy, Michel de Certeau ; no Brasil, mais recentemente, a admirável tese de Claudio Willer, 2010). Alguém deve responder a esse desafio.

\section{Referências Bibliográficas}

ADORNO, Theodor (2009). Dialética negativa. Tradução de Marco Antonio Casanova. Rio de Janeiro: Jorge Zahar.

AGRIPPA, Henricus Cornelius (2007). Declamation on the Nobility and Preeminence of the Female Sex. Chicago: The University of Chicago Press.

BALAKIAN, Anna (1985). O simbolismo. Perspectiva: São Paulo.

BEAUDE, Joseph (1990). La mystique. Paris: Fides.

BENJAMIN, Walter (1972). Gesammelte Schriften III. Org. de Hella Tiedemann-Bartels. Frankfurt am Main: Suhrkamp. (1994). Magia e técnica, arte e política. Ensaios sobre literatura e cultura. São Paulo: Brasiliense.

BLOOM, Harold (1991). Cabala e crítica. Rio de Janeiro: Imago.

BORGES, Jorge Luis (1985). Prólogos: com um prólogo dos prólogos. Rio de Janeiro: Rocco. 
BOSSUET, Jacques Bénigne (1836). Oeuvres complètes de Bossuet: Évêque de Meaux, Band 11. Paris: Lefèvre.

(1841). Oeuvres complètes de Bossuet, Band 14. Paris: Outhenin-Chalandre.

BRETON, André (1986). Arcano 17. São Paulo: Brasiliense.

CAROLlO, Cassiana (1981). Decadismo e simbolismo no Brasil: Critica e poética. Rio de Janeiro: Livros Técnicos e Cientificos Ed.

CERTEAU, Michel de (2015). A fábula mística séculos XVI e XVII: volume 1. Rio de Janeiro: Forense.

CRUZ E SOUSA, João da (1995). Obra completa. Rio de Janeiro: Editora Nova Aguilar.

DAVID-MENARD, Monique (1996). A loucura na razão pura: Kant, leitor de Swedenborg. São Paulo: Ed. 34.

DELEUZE, Gilles (1999). Crítica e clínica. São Paulo: 34.

ECKHART, Johannes (1903). Meister Eckharts mystische Schriften. Tradução e introdução de Gustav Landauer. Berlin: Schnabel.

FOUCAULT, Michel (2000). As palavras e as coisas. Uma arqueologia das ciências humanas. São Paulo: Martins Fontes.

GRUBER, Bettina (org.) (1997). Erfahrung und System: Mystik und Esoterik in der Literatur der Moderne. Opladen: Westdeutscher.

HANEGRAAFF, Wouter J (2012). Esotericism and the academy: rejected knowledge in western culture. Cambridge: Cambridge University Press. (2013). Western esotericism: a guide for the perplexed. London: Bloomsbury.

JAMES, William (1995). As variedades da experiência religiosa: um estudo sobre a natureza humana. Trad. Octavio Mendes Cajado. Cultrix: São Paulo.

KANT, Immanuel (1976). Träume eines Geistersehers, erläutert durch Träume der Metaphysik. Stuttgart: Reclam. (1989). Sueños de un visionario explicados mediante los ensueños de la metafísica. Cadiz: Universidad, D.L.

LESCURE, M. de (1863). Journal et memoires Mathieu Marais. Paris: Firmin Didot frères.

LEWIS, Ioan (1971). Exxtase religioso. Um Estudo Antropológico da Possessão por Espírito e do Xamanismo. São Paulo: Perspectiva.

LIMA, Jorge de (1997). Poesia completa: volume único. Rio de Janeiro: Nova Aguilar.

LÖWY, Michael (1989). Redenção e utopia. O judaísmo libertário na Europa central: um estudo de afinidade eletiva. São Paulo: Companhia das Letras.

MANGABEIRA, Francisco (1906). As visões de Santa Thereza. Porto: Empreza Literária e Typográphica.

MERCIER, Alain (1969). Les Sources ésotériques et occultes de la poésie symboliste (1870-1914): Vol. 1, Le symbolisme Francais. (1870-1914). Paris: A.-G. Nizet. (1974). Les Sources ésotériques et occultes de la poésie symboliste (1870-1914): Vol. 2, Le symbolisme européen (1870-1914). Paris: A.-G. Nizet.

MOISÉS, Massaud (1966). A literatura brasileira: O simbolismo (1893-1902). São Paulo: Cultrix.

MÜLLER, Alois (2003). Wie laizistisch ist Frankreich wirklich? Von der kämpferischen zur offenen Laizität. In: BROCKER, Manfred; BEHR, Hartmut; HILDEBRANDT, Mathias (orgs.). Religion - Staat - Politik: zur Rolle der Religion in der nationalen und internationalen Politik. Wiesbaden: Westdeutscher Verlag.

PAZ, Octavio (1984). Os filhos do barro: do romantismo à vanguarda. Rio de Janeiro: Nova Fronteira.

PIRES, Ericson (2007). Cidade ocupada. Rio de Janeiro: Aeroplano. 
REZENDE, Renato (2007). Linhas de força do contemporâneo - arte brasileira. $270 \mathrm{f}$. Tese (Doutorado em Artes). Instituto de Artes, Universidade do Estado do Rio de Janeiro, Rio de Janeiro.

RIMBAUD, Arthur (2007). Prosa poética. Trad. de Ivo Barroso. Rio de Janeiro: Topbooks.

ROBERTS, Edward A. (2014). A comprehensive etymological dictionary of the Spanish language with families of words based on Indo-European roots/ Volume 1, (A-G). Bloomington: Xlibris.

RUUSBROEC, Jan van (1891). L'ornement des noces spirituelles de Ruysbroeck l'Admirable. Trad. de Maurice Maeterlinck. Bruxelles: P. Lacomblez.

RUYSBROECK L'Admirable (2001). L'ornement des noces spirituelles. Tradução e introdução de Maurice Maeterlinck. Cortaillod: Arbre d'Or.

SCHOLEM, Gerschom (1978 [1960]). A cabala e seu simbolismo. São Paulo: Perspectiva. . (1994). Briefe I. 1914-1947. Org. Itta Shedletzky. München: C. H. Beck. (1962). Ursprung und Anfänge der Kabbala. Berlin: Walter de Gruyter. (1973). Zur Kabbala und ihrer Symbolik. Zürich: Suhrkamp.

VALÉRY, Paul (1957). Cantiques spirituels. In: Oeuvres, vol. I. Paris, Gallimard.

WILLER, Claudio (2010). Um obscuro encanto: gnose, gnosticismo e poesia moderna. Rio de Janeiro: Civilização Brasileira.

WILSON, Edmund (1967). O castelo de Axel: estudo acerca da literatura imaginativa de 1870-1930. São Paulo: Cultrix.

YATES, Frances (1995). Giordano Bruno e a tradição hermética. São Paulo: Cultrix.

Artigo recebido em 21 de novembro de 2018.

Aprovado em 05 de dezembro de 2018. 